\title{
Demogeografski razvoj Baranje 1991.-2001.
}

\author{
Pavo Šašlin
}

\begin{abstract}
U ovom su radu analizirane suvremene demogeografske značajke i procesi u Baranji. Ukazano je na dominantne procese i promjene dinamičnih i strukturnih obilježja stanovništva u zadnjem međupopisnom razdoblju. Uz prikaz prostorne diferencijacije demografskih obilježja, naznačen je i mogući budući demogeografski razvoj ovoga kraja.

Ključne riječi: Baranja, depopulacija, dinamička i strukturna obilježja, društvenogospodarski razvoj, demografske perspektive, revitalizacija
\end{abstract}

\section{Population Development of Baranya 1991-2001 (Croatia)}

This paper analyzes contemporary population features and processes in Baranya. It points to the dominant processes and changes of the population dynamic and structural characteristics in the last inter-census period. Besides the presentation of the demographic feature differentiation, a possible future population development of this region has also been denoted.

Key words: Baranya, depopulation, dynamic and structural features, socio-economic development, demographic perspective, revitalization

\section{UVOD}

Baranja, prostor krajnjeg sjeveroistočnog dijela Hrvatske, omeđen rijekama Dunavom i Dravom te suhozemnom hrvatsko-mađarskom državnom granicom, površinom od 1147 $\mathrm{km}^{2}$ čini 2,0 posto površine Republike Hrvatske. Administrativno-teritorijalno podijeljena je na devet jedinica lokalne samouprave: osam općina (Bilje, Čeminac, Darda, Draž, Jagodnjak, Kneževi Vinogradi, Petlovac i Popovac) i jedan grad (Beli Manastir).

Granični položaj ovog dijela istočnohrvatske ravnice u više se navrata tijekom povijesti pokazao kao izuzetno bitan čimbenik koji je presudno utjecao na razvoj i obilježja baranjske populacije. Zbog rubnog, graničnog položaja i nerijetko suprotstavljenih interesa država glede ovog područja, u njegovu demografskom razvoju često je upravo politički faktor bio izuzetno važan.

I u razdoblju 1991.-2001. u ovom dijelu Hrvatske dogodile su se velike političke, teritorijalne i društveno-gospodarske promjene. Okupacija, progonstvo i rat, potom 
vraćanje tog prostora pod suverenitet Republike Hrvatske, povratak prognanih osoba, ali i proces pretvorbe i privatizacije društvenog vlasništva, rezultiraju velikim političkim i društvenim promjenama, potencirajući specifičnosti demografskih obilježja u pogledu razvoja i gustoće naseljenosti, kretanja ukupnog broja stanovnika, te posebnosti u prirodnoj dinamici i strukturnim obilježjima stanovništva u odnosu na ostali dio županije i državu u cjelini. Neka negativna obilježja i tendencije uočene u ranijim razdobljima, danas su tako još vidljivije.

\section{NASELJENOST}

Oscilacije ukupnog broja stanovnika, koje su obilježile povijesni razvoj naseljenosti Baranje, značajka su i posljednjeg desetljeća 20. stoljeća. Društveno-povijesna zbivanja krajem prošlog stoljeća bitno su utjecala na najveće međupopisno smanjenje broja stanovnika od kada se provode popisi stanovništva na ovim prostorima (tab. 1).

Tab. 1 Razvoj ukupnog broja stanovništva Baranje 1857-2001

Tab. 1 Total population number change in Baranya 1857-2001

\begin{tabular}{|c|c|c|c|c|c|c|}
\hline $\begin{array}{l}\text { Godi- } \\
\text { na } \\
\text { popisa }\end{array}$ & $\begin{array}{l}\text { Broj } \\
\text { stano- } \\
\text { vnika }\end{array}$ & $\begin{array}{l}\text { Porast (pad) } \\
\text { u odnosu na } \\
\text { preth. razdob. }\end{array}$ & $\begin{array}{l}\text { Veri- } \\
\text { žni } \\
\text { indeks }\end{array}$ & $\begin{array}{l}\text { Indeks } \\
\mathbf{1 8 5 7}=\mathbf{1 0 0}\end{array}$ & $\begin{array}{l}\text { Stopa prosječne god. } \\
\text { promjene izmedu } \\
\text { dva popisa (u\%) }\end{array}$ & $\begin{array}{l}\text { Udjel u } \\
\text { stanovništvu } \\
\text { RH (u\%) }\end{array}$ \\
\hline 1857. & 39895 & $\mathbf{2}$ & $\mathbf{3}$ & $\mathbf{4}$ & $\mathbf{5}$ & $\mathbf{6}$ \\
\hline 1869. & 44336 & 4441 & 111,1 & 111,1 & 0,88 & 1,8 \\
\hline 1880. & 44782 & 446 & 101,0 & 112,2 & 0,09 & 1,8 \\
\hline 1890. & 48237 & 3455 & 107,7 & 120,9 & 0,74 & 1,8 \\
\hline 1900. & 48960 & 723 & 101,5 & 122,7 & 0,15 & 1,7 \\
\hline 1910. & 50943 & 1983 & 104,1 & 127,7 & 0,40 & 1,5 \\
\hline 1921. & 49173 & -1770 & 96,5 & 123,3 & $-0,32$ & 1,5 \\
\hline 1931. & 51976 & 2803 & 105,7 & 130,3 & 0,55 & 1,4 \\
\hline 1948. & 53417 & 1441 & 102,8 & 133,9 & 0,16 & 1,4 \\
\hline 1953. & 50866 & -2551 & 95,2 & 127,5 & $-0,98$ & 1,3 \\
\hline 1961. & 56087 & 5221 & 110,3 & 140,6 & 1,22 & 1,3 \\
\hline 1971. & 56322 & 235 & 100,4 & 141,2 & 0,04 & 1,3 \\
\hline 1981. & 53409 & -2913 & 94,8 & 133,9 & $-0,53$ & 1,2 \\
\hline 1991. & 54265 & 856 & 101,6 & 135,7 & 0,16 & 1,1 \\
\hline 2001. & 42633 & -11632 & 78,6 & 106,9 & $-2,40$ & 1,0 \\
\hline
\end{tabular}

Izvor: M. Korenčić: Naselja i stanovništvo SRH 1857-1971, JAZU, Knjiga 54, Zagreb, 1979. Dokumentacija 551. RZS, Zagreb, 1982. Popis stanovništva 1991. Stanovništvo prema narodnostima po naseljima. Dokumentacija 881 RZS, Zagreb, 1992., Popis stanovništva 2001., DZS, Zagreb, 2002. 


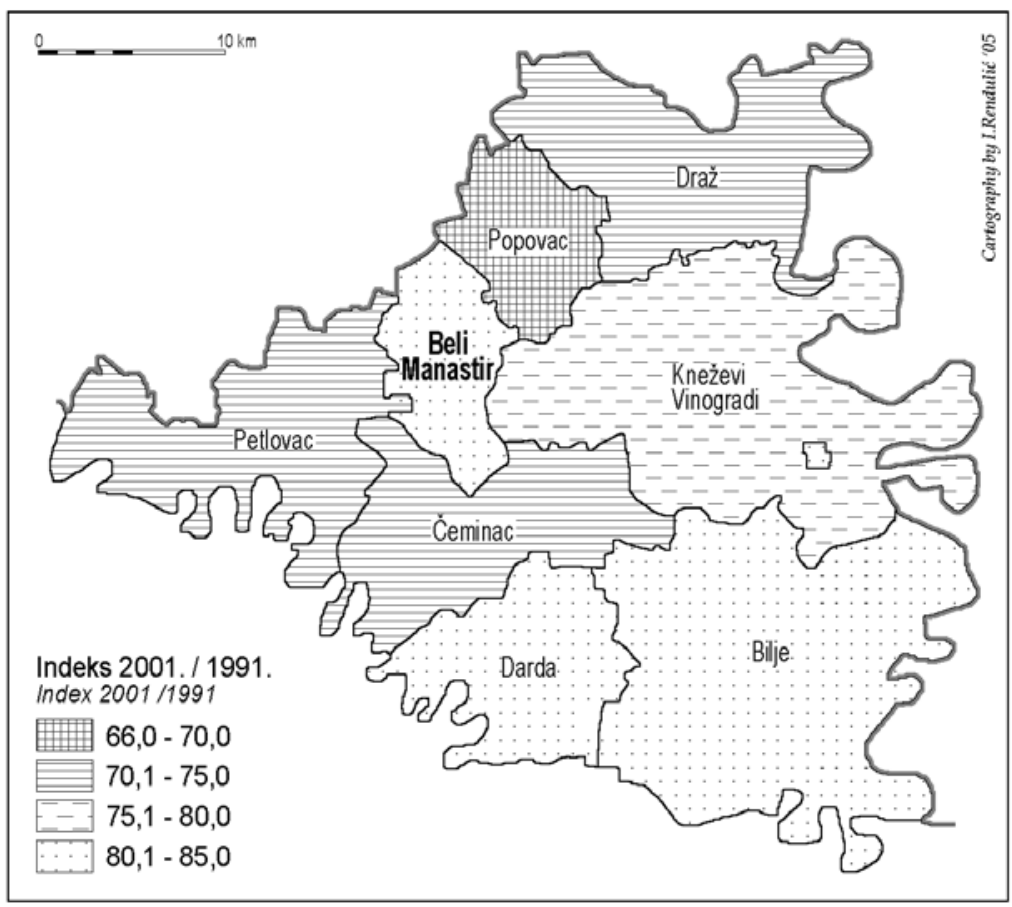

S1. 1. Promjena broja stanovnika općine Baranja i grada Belog Manastira u razdoblju 1991-2001.

Fig. 1 Population number change in the municipalities of Baranya and in the city of Beli Manastir 1991-2001.

Tijekom posljednjeg međupopisnog razdoblja, uslijed progonstva kao posljedice okupacije, gubitaka u ratu, daljnjeg pogoršanja prirodnog kretanja, izostanka povratka i iseljavanja nakon reintegracije, ukupan broj stanovnika smanjen je za više od petine u odnosu na 1991. godinu. Današnjih 42633 stanovnika čini tek 0,96 posto pučanstva Hrvatske. Opća gustoća naseljenosti je 37,2 stanovnika po četvornom kilometru, što je više nego upola manja gustoća naseljenosti u odnosu na Osječko-baranjsku županiju (79,6 stanovnika po četvornom kilometru), čiji je integralni dio.

Na snažnu depopulaciju kao dominantno obilježje demografskih kretanja u Baranji ukazuje i činjenica da je broj stanovnika smanjen u svim jedinicama lokalne samouprave (sl. 1), dok je na razini naselja samo u jednom naselju broj stanovnika ostao isti kao i prije deset godina. ${ }^{2}$ Činjenica da od ukupno 52 naselja niti u jednom naselju nije došlo do pozitivne promjene broja stanovnika dovoljno govori o intenzitetu demografske regresije u zadnjih deset godina. Samo u dva naselja to je smanjenje manje od 10,0 posto, dok je kod nekih manjih naselja broj stanovnika više nego prepolovljen (Zlatna Greda, Tikveš, Širine,....)

Prostorno, smanjenje ukupnog broja stanovnika izraženije je u rubno smještenim naseljima (sl. 2), na krajnjem sjeveroistoku i zapadu, a manje u naseljima središnjeg i južnog dijela. Odraz je to prometne povezanosti, prostornog razmještaja gospodarskih kapaciteta i aktivnosti, te prometne i funkcionalne povezanosti s Osijekom. 


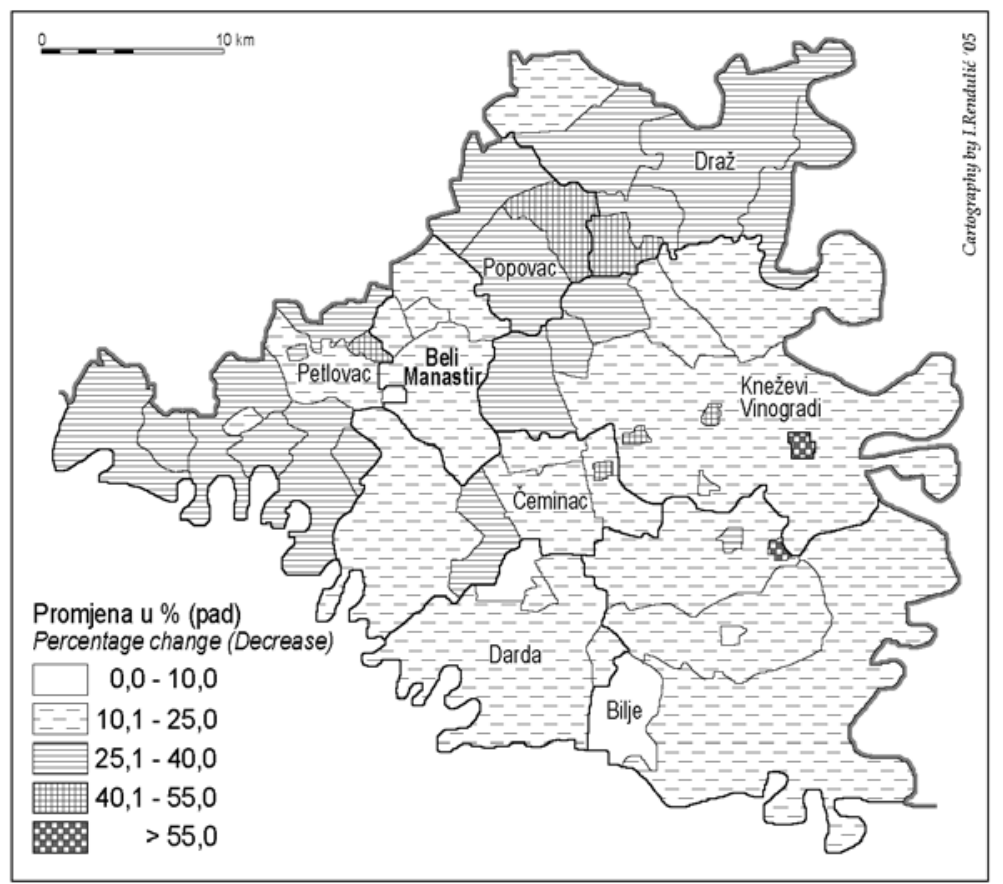

S1. 2. Promjena broja stanovnika Baranje po naseljima 1991-2001.

Fig. 2 Population number change in Baranya by settlements 1991-2001.

Iako su tendencije demografskog pražnjenja pojedinih dijelova Baranje bile uočene i u ranijim razdobljima, u prošlom desetljeću demografska regresija je postala glavno obilježje demografskih kretanja cjelokupnog prostora. Smanjenje ukupnog broja stanovnika u razdoblju 1991.-2001., obilježje je Baranje kao cjeline, svih njenih sastavnica (upravno-teritorijalnih jedinica) i de facto svih naselja.

\section{DINAMIČKA OBILJEŽJA STANOVNIŠTVA}

Iako za posljednje međupopisno razdoblje nije moguće odrediti tip općeg kretanja stanovništva, budući da zbog okupiranosti područja od 1991. do 1998. godine nema podataka vitalne statistike, već i na temelju popisne promjene 1991.-2001., koja pokazuje smanjenje broja stanovnika od čak 11 632, odnosno 21,4 posto, sasvim je jasno o kojem bi se tipu općeg kretanja stanovništva moglo raditi. Demografsko izumiranje, više je nego očito.

Pojačani denatalitet, odnosno negativna prirodna promjena stanovništva, uočena je u Baranji već 1989. i 1990. godine, dakle dvije godine ranije nego na razini države. Od 1991. do 1998. godine službenih podataka o prirodnom kretanju stanovništva ovog dijela Istočne Hrvatske nema, no podaci o prirodnom kretanju stanovništva od 1998. do 2001. potvrđuju realnost, s obzirom na okolnosti, očekivanog nastavka i ubrzanja nepovoljne dinamike prirodnog kretanja ${ }^{4}$ i daljnjeg produbljenja biološke depresije. 
Tab. 2. Prirodno kretanje stanovništva Baranje po upravno-teritorijalnim jedinicama i ukupno Republike Hrvatske 1998-2001 (u \%o)

Tab. 2 Natural population change in Baranya by administrative-territorial units and total population change in the Republic of Croatia 1998-2001 (in \%o)

\begin{tabular}{|l|r|r|r|r|r|r|r|r|r|r|r|r|r|r|r|r|}
\hline \multirow{2}{*}{$\begin{array}{l}\text { Općina/ } \\
\text { Grad }\end{array}$} & \multicolumn{4}{|c|}{ Rodnost } & \multicolumn{4}{|c|}{ Smrtnost } & \multicolumn{3}{|c|}{ Prirodna promjena } \\
\hline & 1998 & 1999 & 2000 & 2001. & ggod. & 1998 & 1999 & 2000 & 2001. & Øgod. & 1998 & 1999. & 2000. & 2001. & Øgod. \\
\hline B. Manastir & 8,8 & 7,2 & 8,3 & 6,6 & 7,7 & 10,6 & 12,7 & 9,8 & 9,6 & 10,7 & $-1,8$ & $-5,5$ & $-1,5$ & $-3,0$ & $-3,0$ \\
\hline Bilje & 7,3 & 11,1 & 10,2 & 10,2 & 9,7 & 11,5 & 13,8 & 9,5 & 10,6 & 11,4 & $-4,2$ & $-2,7$ & 0,7 & $-0,4$ & $-1,7$ \\
\hline Čeminac & 6,3 & 12,3 & 8,8 & 10,9 & 9,6 & 9,8 & 11,2 & 15,4 & 12,6 & 12,3 & $-3,5$ & 1,1 & $-6,7$ & $-1,8$ & $-2,7$ \\
\hline Darda & 8,6 & 11,3 & 10,8 & 8,5 & 9,8 & 11,3 & 10,9 & 12,3 & 11,0 & 11,4 & $-2,7$ & 0,4 & $-1,6$ & $-2,5$ & $-1,6$ \\
\hline Draž & 6,0 & 7,2 & 8,0 & 7,2 & 7,1 & 25,9 & 17,3 & 20,0 & 24,1 & 21,8 & $-20,0$ & $-10,1$ & $-11,9$ & $-17,0$ & $-14,8$ \\
\hline Jagodnjak & 8,3 & 7,1 & 4,7 & 7,1 & 6,8 & 13,8 & 16,9 & 19,3 & 14,2 & 16,1 & $-5,5$ & $-9,9$ & $-14,6$ & $-7,1$ & $-9,3$ \\
\hline K. Vinogradi & 8,1 & 8,5 & 7,7 & 6,7 & 7,8 & 22,4 & 18,5 & 13,7 & 14,8 & 17,4 & $-14,3$ & $-10,0$ & $-6,0$ & $-8,1$ & $-9,6$ \\
\hline Petlovac & 7,3 & 12,4 & 10,9 & 12,8 & 10,9 & 19,7 & 15,7 & 18,2 & 13,5 & 16,8 & $-12,4$ & $-3,3$ & $-7,3$ & $-0,7$ & $-5,9$ \\
\hline Popovac & 5,8 & 9,1 & 6,2 & 7,8 & 7,2 & 14,8 & 20,2 & 14,4 & 17,7 & 16,8 & $-9,1$ & $-11,1$ & $-8,2$ & $-9,9$ & $-9,6$ \\
\hline Baranja & $\mathbf{7 , 8}$ & $\mathbf{9 , 3}$ & $\mathbf{8 , 7}$ & $\mathbf{8 , 2}$ & $\mathbf{8 , 5}$ & $\mathbf{1 4 , 4}$ & $\mathbf{1 4 , 4}$ & $\mathbf{1 3 , 2}$ & $\mathbf{1 2 , 9}$ & $\mathbf{1 3 , 7}$ & $\mathbf{- 6 , 6}$ & $\mathbf{- 5 , 1}$ & $\mathbf{- 4 , 5}$ & $\mathbf{- 4 , 7}$ & $\mathbf{- 5 , 2}$ \\
\hline HRVATSKA & 10,5 & 9,9 & 10,0 & 9,2 & 9,9 & 11,6 & 11,4 & 11,5 & 11,2 & 11,4 & $-1,2$ & $-1,5$ & $-1,5$ & $-1,5$ & $-1,9$ \\
\hline
\end{tabular}

Izvor: Prirodno kretanje stanovništva u 1998., 1999., 2000. i 2001. DZS, Zagreb.

O intenzitetu prirodne depopulacije u tom razdoblju kazuje i podatak da su evidentirana samo 1453 živorođena djeteta, dok je broj umrlih 2344, pa je vitalni indeks bio 62,0. Prirodno kretanje stanovništva Baranje od 1998. do 2001. (tab. 2), obilježava izuzetno niska vrijednost prosječne godišnje stope rodnosti ( 8,5 promila) i razmjerno visoka vrijednost prosječne godišnje stope smrtnosti ( 13,7 promila). S obzirom na takve vrijednosti stopa, očito da je osim denataliteta i smrtnost postala vrlo važna odrednica negativnog prirodnog kretanja baranjskog pučanstva, što je odraz i njegove dobne strukture.

U usporedbi s Hrvatskom, u svim promatranim godinama vrijednosti stope nataliteta su niže, a stope mortaliteta više nego na razini države, dok je negativna vrijednost prosječne godišnje stope prirodne promjene trostruko veća nego u Hrvatskoj. Prirodna, reprodukcijska depopulacija, očito je u Baranji znatno izraženija nego na prostoru Hrvatske u cjelini. Razlozi tomu su višestruki: ratni gubici, manja brojnost generacija u fertilnoj dobi zbog niskog nataliteta u ranijim razdobljima, izostanak povratka stanovništva mlađe dobi, odlazak mlađeg srpskog stanovništva nakon uspostave ustavno-pravnog poretka Republike Hrvatske.

Temeljom predočenih podataka s pravom se može ustvrditi da je negativno prirodno kretanje vrlo bitan faktor depopulacije u ovom dijelu hrvatskog Podunavlja, te da je posljedica niske stope rađanja, ali sve više i povećanja stope umiranja, budući obje "sve više postaju funkcija dobne strukture i bioloških determinanti” (Šterc, S., 1983: 121). 
Migracije koje su obilježile zadnje desetljeće prošlog stoljeća u Baranji i u Hrvatskoj, ali i na većem dijelu bivše države, uzrokovane su prvenstveno političkim razlozima. U Baranji migracije su bile inicirane okupacijom i ratom te njenom reintegracijom u ustavno-pravni sustav Republike Hrvatske. Kao i prijašnje migracije tijekom povijesti i ove su bile bitna odrednica kako brojčanog razvoja stanovništva, tako i oblikovanja svih njegovih značajki, poglavito strukturnih obilježja.

Okupacija Baranje, koja je i formalno realizirana koncem kolovoza 1991. godine, prouzročila je prisilne migracije stanovništva, migracije u kojoj osobe moraju seliti i nemaju mogućnosti izbora (Wertheimer-Baletić, A., 1999). Prema podacima Popisa 1991., provedenog samo nekoliko mjeseci prije okupacije, u ovom dijelu Hrvatske živjelo je 54265 stanovnika. Srpska agresija rezultirala je okupacijom svih naselja ${ }^{5}$ i gotovo cjelokupnog teritorija Baranje. ${ }^{6}$ Uslijedilo je etničko čišćenje ovog dijela hrvatskog Podunavlja, uz istodobni proces sustavnog naseljavanja srpskog stanovništva, u početku s prostora Srbije, a potom i iz zapadne Slavonije i Bosne. Prema „popisu“ stanovništva koji je srpska okupacijska vlast provela u razdoblju od 27. siječnja do 05. ožujka 1992. godine, ukupno je evidentirano 39482 stanovnika, dakle 14783 stanovnika (27,2 posto) manje u odnosu na broj stanovnika evidentiran redovnim Popisom 1991. godine. Treba reći da se tim okupacijskim "popisom" u ukupnom broju stanovnika našlo i 5874 tzv. "izbegla lica”, kako su tada službeno nazivali osobe koje su doseljene u Baranju nakon okupacije. To znači da je broj prijeratnog baranjskog stanovništva smanjen za 20657 osoba, odnosno čak 38,1 posto u odnosu na 1991. godinu. Dakle, okupacija je bila uzrokom migracija kojima je do početka ožujka 1992. godine bilo obuhvaćeno 26531 osoba (20 657 prognanih i 5874 doseljenih), a čime je radikalno izmijenjena i etnička slika baranjskog prostora.

Protjerivanja, odnosno prisilne migracije nesrpskog stanovništva i naseljavanje srpskog stanovništva, nastavljeno je i nakon spomenutog "popisa", tijekom narednih godina, no nakon 1992. nema preciznijih podataka na osnovi kojih bi se moglo govoriti o intenzitetu i obilježjima migracijskih kretanja u Baranji.

Nakon reintegracije uslijedile su nove migracije; povratak prognanih i odlazak doseljenog, ali i dijela prijeratnog srpskog stanovništva.

Dakako, sve te migracije u konačnici su rezultirale velikim promjenama, kako u pogledu smanjenja ukupnog broja stanovnika i izmjene etničkog sastava, tako i glede jačanja nepovoljnih strukturnih obilježja stanovništva Baranje.

\section{STRUKTURNA OBILJEŽJA STANOVNIŠTVA}

Promjene u strukturama stanovništva prema spolu, dobi, ekonomskim i drugim obilježjima, primarna su odrednica prirodnog kretanja stanovništva. Upravo navedene strukture, posebno ekonomsko-socijalna, odražavaju promjene društvenih i gospodarskih uvjeta života i izravno utječu na natalitet i mortalitet. Proučavanje struktura stanovništva omogućuje spoznaju bitnih značajki i odrednica ukupnog kretanja stanovništva, cjelokupnog razvoja stanovništva te određivanje uloge ljudskog faktora u gospodarskom razvoju određenog prostora (Wertheimer-Baletić, A., 1999). 
Tab. 3. Spolna struktura stanovništva Baranje i Hrvatske 1991. i 2001.

Tab. 3 Baranya and Croatia: sex structure of population in 1991 and 2001

\begin{tabular}{|c|c|c|c|c|c|c|}
\hline \multirow{2}{*}{$\begin{array}{l}\text { Godina } \\
\text { popisa }\end{array}$} & \multicolumn{3}{|c|}{ Baranja } & \multicolumn{3}{c|}{ Republika Hrvatska } \\
\cline { 2 - 7 } & broj žena & \% u uk.st. & kf & broj žena & \% u uk.st. & kf \\
\hline 1991. & 27902 & 51,4 & 105,8 & 2301560 & 51,5 & 106,3 \\
\hline 2001. & 22221 & 52,1 & 108,9 & 2465642 & 51,9 & 107,8 \\
\hline
\end{tabular}

Izvor: Popis stanovništva 1991. Stanovništvo prema spolu i starosti. Dokumentacija 882 DZS, Zagreb, 1992., Popis stanovništva 2001., DZS, Zagreb, 2002.

Na strukturu stanovništva prema spolu u Baranji, kao uostalom i u cijeloj Hrvatskoj, pored višegodišnjeg utjecaja prirodnog i mehaničkog kretanja stanovništva, bitno je utjecao i rat kao vanjski čimbenik.

Udio žena u ukupnoj baranjskoj populaciji, odnosno koeficijent feminiteta, 1991. godine je bio nešto niži nego u Hrvatskoj (tab. 3). Deset godina kasnije udio žena u ukupnom stanovništvu, kao i koeficijent feminiteta, je viši nego na razini države. Veći udio žena u ovom slučaju nikako ne ukazuje na veću gospodarsku razvijenost tog dijela Hrvatske, već je on posljedica većeg stradavanja muškog dijela stanovništva tijekom okupacije i rata te starenja ukupne populacije.

Već početkom devedesetih godina prošlog stoljeća dobnu strukturu stanovništva Baranje obilježavalo je vrlo brzo starenje i vrlo visoki stupanj ostarjelosti. Godine 1991., udjelom mladih (0-19 godina) od 26,3 posto i starih (60 i više godina) od 17,5 posto, dobna struktura stanovništva Baranje bila je vrlo slična dobnoj strukturi stanovništva cijele države (tab. 3). Te godine indeks starosti ${ }^{7}$ stanovništva Baranje je bio tek nešto niži od indeksa starosti stanovništva države.

Tab. 4. Dobna struktura stanovništva Baranje i Hrvatske 1991. i 2001.

Tab. 4 Baranya and Croatia: age structure of population in1991 and 2001

\begin{tabular}{|r|r|r|r|r|r|r|r|r|}
\hline & \multicolumn{4}{|c|}{ 1991. } & \multicolumn{3}{c|}{ 2001. } & \multicolumn{2}{c|}{$\begin{array}{c}\text { Indeks staro- } \\
\text { sti (\%) }\end{array}$} \\
\cline { 2 - 9 } & $\mathbf{0 - 1 9}$ & $\mathbf{2 0 - 5 9}$ & $\mathbf{6 0}$ i više & $\mathbf{0 - 1 9}$ & $\mathbf{2 0 - 5 9}$ & $\mathbf{6 0}$ i više & 1991. & $\mathbf{2 0 0 1 .}$ \\
\cline { 2 - 10 } & $\mathbf{1}$ & $\mathbf{2}$ & $\mathbf{3}$ & $\mathbf{4}$ & $\mathbf{5}$ & $\mathbf{6}$ & $\mathbf{7}$ & $\mathbf{8}$ \\
\hline $\begin{array}{r}\text { Baranja } \\
\text { aps. } \\
\text { rel. }\end{array}$ & 14131 & 30240 & 9398 & 9868 & 22927 & 9745 & 66,5 & 98,8 \\
\cline { 2 - 10 } & 26,3 & 56,2 & 17,5 & 23,2 & 53,9 & 22,9 & & \\
\hline Hrvatska & & & & & & & & \\
\hline aps. & 1252469 & 2624801 & 834988 & 1053240 & 2409359 & 955556 & 66,7 & 90,7 \\
\hline rel. & 26,6 & 55,7 & 17,7 & 23,8 & 54,6 & 21,6 & & \\
\hline
\end{tabular}

Izvor: Popis stanovništva 1991. Stanovništvo prema spolu i starosti. Dokumentacija 882 DZS Zagreb, 1992., Popis stanovništva 2001., DZS, Zagreb, 2002. 
Deset godina kasnije, 2001. godine, vrijednosti indeksa starosti su znatno više i u Baranji i u državi u cjelini. Obilježja tipa dobnog sastava duboka starost, uočena već 1991., u Baranji su sada izraženija nego u Republici Hrvatskoj i dobni je sastav sasvim blizu tipu izrazito duboka starost. ${ }^{9}$

Vrlo naglašen proces starenja stanovništva očito je bitna značajka ovog područja. Baranja je postala prostorom staračkih domaćinstava, bez mladeži i nasljednika, a što je posljedica poglavito niskog nataliteta, ruralnog egzodusa i negativnih demografskih kretanja vezanih uz Domovinski rat. Negativne značajke demografskog razvoja imaju tendenciju daljnjeg pogoršanja, tako da i tip dobnog sastava duboka starost postaje upitan $\left(\mathrm{x}_{\mathrm{s} 2001}=98,8\right.$ posto $)$.

Dobni sastav je obilježje stanovništva koje presudno utječe na buduće kretanju broja stanovnika, kako područja u cjelini, tako i pojedinih naselja, a odražava se i na gospodarske, kulturne i ukupne društvene aktivnosti. Stoga je, s obzirom na sadašnju dobnu strukturu, razumljiv pesimizam glede demografske, ali i ukupne društveno-gospodarske perspektive ovog kraja. "U društvu u kojem je postotak starih ljudi pretjerano velik očigledno je teško uspostaviti zadovoljavajući i uravnotežen socijalni život. Štoviše može se smatrati da starenje ima reperkusije na mentalitet, na nivo optimizma i duh poduzetništva stanovništva" (Mendras, H., 1986: 205, 206). “Takvo stanje nedvojbeno utječe kod preostalog mladog naraštaja na odluku o odlasku iz sela, produbljuje demografsku i socijalnu depresiju i tako ograničava mogućnosti stabiliziranja i preokreta nepovoljnih demografskih i općerazvojnih tendencija" (Nejašmić, I., 1991b: 228).

Budući da je obrazovanje bitna pretpostavka za obavljanje složenijih poslova, ono je ujedno i pretpostavka i posljedica promjena u strukturi stanovništva prema aktivnosti, djelatnosti i zanimanju, koje nastaju usporedo s gospodarskim razvojem.

Tab. 5. Nepismeno, bez školske spreme i visokoobrazovano stanovništvo starije od 15 godina u Baranji i Hrvatskoj 1991.

Tab. 5 Baranya and Croatia in 1991: population older than 15 years - illiterate, without educational qualification and that of university education

\begin{tabular}{|l|c|c|c|c|c|c|c|}
\hline \multirow{2}{*}{} & \multirow{2}{*}{$\begin{array}{c}\text { Broj } \\
\text { stanovnika }\end{array}$} & \multicolumn{2}{c|}{$\begin{array}{c}\text { Broj nepismenih } \\
\text { stanovnika }\end{array}$} & \multicolumn{2}{c|}{$\begin{array}{c}\text { Broj stanovnika bez } \\
\text { školske spreme }\end{array}$} & \multicolumn{2}{c|}{$\begin{array}{c}\text { Broj visokoobrazo- } \\
\text { vnog stanovništva }\end{array}$} \\
\cline { 2 - 8 } & $\mathbf{1}$ & $\mathbf{2}$ & $\mathbf{3}$ & $\mathbf{4}$ & $\mathbf{5}$ & $\mathbf{6}$ & $\mathbf{7}$ \\
\cline { 2 - 8 } & $\mathbf{1}$ & $\mathbf{\%}$ & aps. & $\mathbf{\%}$ & aps. & $\mathbf{\%}$ \\
\hline Baranja & 43590 & 1937 & 4,4 & 2940 & 6,7 & 1951 & 4,5 \\
\hline Hrvatska & 3858086 & 124236 & 3,2 & 204591 & 5,3 & 360218 & 9,3 \\
\hline
\end{tabular}

Izvor: Popis stanovništva 1991. Stanovništvo prema školskoj spremi, pismenosti i spolu po naseljima, Dokumentacija 884, DZS, Zagreb, 1994.

Obrazovna struktura stanovništva Baranje 1991. godine bila je nepovoljnija u svim promatranim segmentima u odnosu na obrazovnu strukturu stanovništva države (tab. 5). Unatoč poboljšanju obrazovne strukture u zadnjem međupopisnom razdoblju, zaostajanje u odnosu na obrazovnu strukturu stanovništva starijeg od 15 godina na razini države 2001. godine je još izraženije (tab. 6). Danas je u Baranji gotovo dvostruko veći udio 
Tab 6. Nepismeno, bez školske spreme i visokoobrazovano stanovništvo starije od 15 godina u Baranji i Hrvatskoj 2001

Tab. 6 Baranya and Croatia in 2001: population older than 15 years - illiterate, without educational qualification and that of university education

\begin{tabular}{|c|c|c|c|c|c|c|c|}
\hline & \multirow[t]{2}{*}{$\begin{array}{c}\text { Broj } \\
\text { stanovnika }\end{array}$} & \multicolumn{2}{|c|}{$\begin{array}{c}\text { Broj nepismenih } \\
\text { stanovnika }\end{array}$} & \multicolumn{2}{|c|}{$\begin{array}{l}\text { Broj stanovnika bez } \\
\text { školske spreme }\end{array}$} & \multicolumn{2}{|c|}{$\begin{array}{c}\text { Broj visokoobrazo- } \\
\text { vnog stanovništva }\end{array}$} \\
\hline & & aps. & $\%$ & aps. & $\%$ & aps. & $\%$ \\
\hline & 1 & 2 & 3 & 4 & 5 & 6 & 7 \\
\hline Baranja & 35683 & 1149 & 3,2 & 1592 & 4,5 & 2107 & 5,9 \\
\hline Hrvatska & 3682826 & 68986 & 1,9 & 105332 & 2,9 & 438034 & 11,9 \\
\hline
\end{tabular}

Izvor: Popis stanovništva 2001. DZS, Zagreb, 2002.

nepismenih i stanovništva bez stručne spreme, a upola manji udio visokoobrazovanih $\mathrm{u}$ odnosu na udio tih kategorija stanovništva u ukupnom stanovništvu starijem od 15 godina u državi. Iako je ovaj dio Hrvatske oduvijek zbog blizine Osijeka, privlačnosti i prednosti života u urbanoj sredini, "gubio" dio svoje visokoobrazovane populacije, okupacija i rat dodatno su pridonijeli sadašnjem stanju. S jedne strane nedostatak sredstava potrebnih za nastavak obrazovanja u uvjetima progonstva, a s druge veća mogućnost zapošljavanja visokoobrazovanih osoba, a potom i njihov ostanak u mjestima "privremenog boravka", bitno su utjecali na slabije povećanje u usporedbi s rastom udjela ove kategorije u ukupnom stanovništvu starijem od 15 godina na razini države.

Zaostajanje glede obrazovne strukture u odnosu na Hrvatsku, poglavito udjela visokoobrazovanog stanovništva, vrlo je zabrinjavajuće. Nedovoljna zastupljenost visokoobrazovanih kadrova mora se ocjenjivati po njihovoj ključnoj ulozi u generiranju znanja i tehničkog napretka pa se takva struktura ocjenjuje kao nepovoljna s razvojnog stajališta (Wertheimer-Baletić, A., 1988). Upravo je ovom području, uz kapital, prijeko potreban i visokoobrazovan, stručan ljudski potencijal koji bi bio u stanju pokrenuti bržu i snažniju obnovu gospodarskih i društvenih aktivnosti, sanirati posljedice okupacije i rata te tako revitalizirati ovaj dio Hrvatske.

Sadašnja obrazovna struktura, uz postojeća obilježja biološke strukture stanovništva, zasigurno ne budi nadu i potrebno društveno-gospodarsko oživljavanje tog prostora $\mathrm{u}$ ovakvim uvjetima čini se vrlo upitnim.

Struktura aktivnog stanovništva čini polaznu osnovu za proučavanje gospodarske strukture ukupnog stanovništva, budući je upravo aktivno stanovništvo (radna snaga) nositelj proizvodnje i svekolikog gospodarskog i društvenog razvoja. Stoga je bitan udio aktivnog stanovništva u ukupnom stanovništvu, odnosno, opća stopa aktivnosti ukupnog stanovništva.

Godine 1991. opća stopa aktivnosti stanovništva u Baranji je bila niža nego na razini cijele države (tab. 7). Deset godina kasnije, udio aktivnog stanovništva u ukupnoj populaciji povećan je i u Baranji i u državi, no povećanje opće stope aktivnosti ukupnog stanovništva u Baranji je slabije izraženo nego na razini cijele Hrvatske. Pored toga, to povećanje stope aktivnosti stanovništva nije rezultat povećanja broja aktivnog stanovništva, budući je taj broj zbog starenja populacije i drugih negativnih procesa manji nego prije deset godina, već je posljedica velikog smanjenja ukupnog broja stanovnika. 
Tab. 7. Broj aktivnog stanovništva, opća stopa aktivnosti i indeks promjene broja aktivnog stanovništva Baranje i Hrvatske 1991. i 2001.

Tab. 7 Baranya and Croatia in 1991 and 2002: number of active population, general activity rate and change index of active population number

\begin{tabular}{|c|c|c|c|c|c|}
\hline & \multicolumn{2}{|r|}{1991.} & \multicolumn{2}{|r|}{2001.} & \multirow{2}{*}{$\begin{array}{c}\text { Indeks } \\
\text { 2001/1991 }\end{array}$} \\
\hline & $\begin{array}{c}\text { aktivno } \\
\text { (aps.) }\end{array}$ & $\begin{array}{c}\text { opća stopa } \\
\text { aktivnosti (\%) }\end{array}$ & $\begin{array}{c}\text { aktivno } \\
\text { (aps.) }\end{array}$ & $\begin{array}{c}\text { opća stopa } \\
\text { aktivnosti (\%) }\end{array}$ & \\
\hline & 1 & 2 & 3 & 4 & 5 \\
\hline Baranja & 19067 & 35,1 & 17446 & 40,9 & 91,5 \\
\hline Hrvatska & 1811084 & 37,9 & 1952619 & 44,0 & 107,8 \\
\hline
\end{tabular}

Izvor: Popis stanovništva 1991., Dokumentacija 885, DZS, 1994. Popis stanovništva 2001., DZS, Zagreb, 2002.

Smanjenje apsolutnog broja aktivnog stanovništva može se objasniti brojnim društvenim i gospodarskim čimbenicima; emigracijom stanovništva prvenstveno u radno-aktivnoj dobi, procesom deagrarizacije, posljedica čega je transfer stanovništva iz poljoprivrede (s višim stopama aktivnosti) u nepoljoprivredne djelatnosti (s nižim stopama aktivnosti), školovanjem većeg broja mladeži kao i duljim trajanjem školovanja, povećanjem broja osoba koje odlaze u mirovinu i sl. (Wertheimer-Baletić, A., 1978). Posljedica okupacije, rata i reintegracije je i ostanak dijela radno-aktivnog stanovništva u mjestima gdje su boravili za vrijeme progonstva, povećanje broja umirovljenika i invalida mlađe životne dobi. Tome valja dodati odlazak mlađeg, radno-aktivnog (poglavito muškog) dijela srpskih obitelji zbog neprihvaćanja političko-teritorijalne realnosti, odnosno ostanak neaktivnog dijela tih obitelji; zbog mirovine, rješavanja imovinsko-pravnih obiteljskih poslova prije konačnog preseljenja, odbijanja odlaska u novu sredinu s mlađim dijelom obitelji iz psiholoških razloga $\mathrm{i}$ dr.

\section{PROSTORNA DIFERENCIJACIJA DEMOGRAFSKIH OBILJEŽJA I MOGUĆNOSTI REVITALIZACIJE}

Prostorna diferencijacija demografskih obilježja, kao rezultat utjecaja društvenih i gospodarskih čimbenika, vidljiva je na slijedećem prikazu (slika 3). Koncentracija stanovništva je u središnjem, gospodarski vitalnijem dijelu, uz glavnu cestovnu i željezničku komunikaciju. Ključne točke na toj "potencijalnoj razvojnoj i revitalizacijskoj osovini”" su najveća baranjska naselja; Beli Manastir, najznačajnije ekonomsko i populacijsko žarište, Darda, baranjski sekundarni centar i Bilje, koje je s većim dijelom istoimene općine dio gravitacijskog područja Osijeka. U tim naseljima živi najveći dio stanovništva istoimenih općina i grada (u Bilju 58,8 posto, Dardi 76,4 a u Belom Manastiru čak 78,9 posto), a stanovništvo tih upravno-teritorijalnih jedinica čini 55,2 posto baranjskog stanovništva.

Nasuprot tom dijelu, rubni, izrazito ruralni prostori populacijski se prazne, poglavito sjeveroistočni, koji i s obzirom na ukupno stanje društvenog života ima sve značajke prostora socio-demografske depresije. 


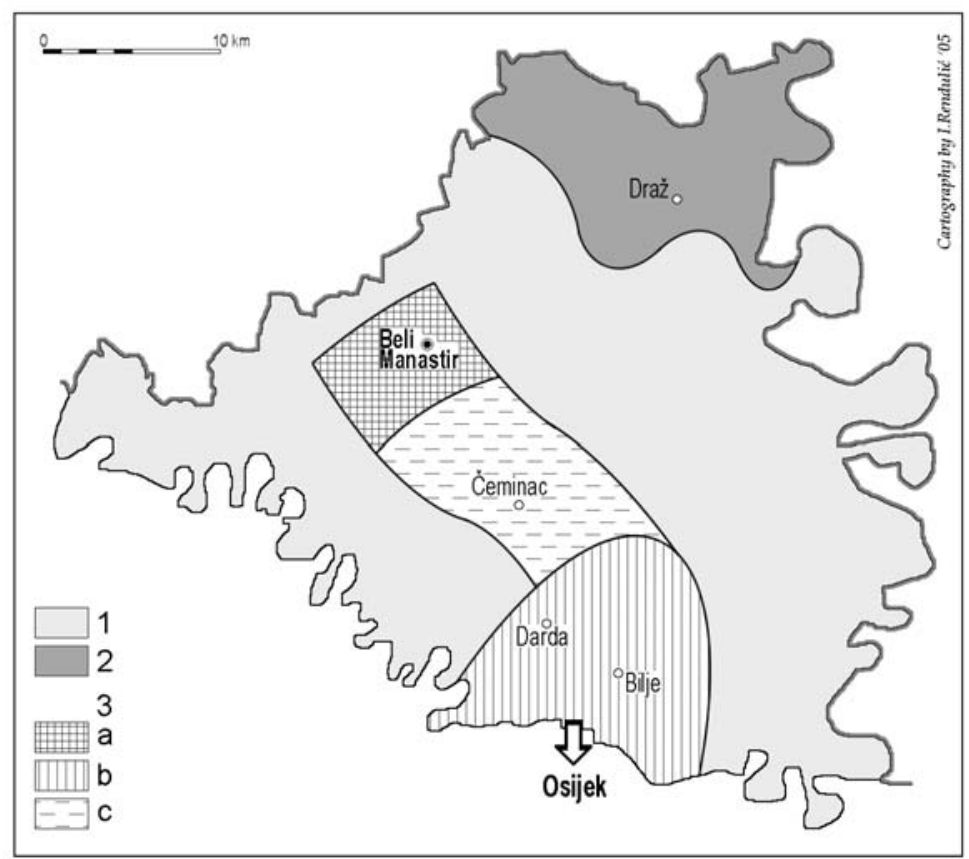

S1. 3. Prostorna diferencijacija suvremenih demografskih značajki Baranje: 1. prostor jače depopulacije, 2. prostor socio-demografske depresije, 3. potencijalna baranjska razvojna osovina (a - populacijsko žarište, b - gravitacijsko područje Osijeka, c - spojni prostor moguće brže revitalizacije)

Fig. 3 Spatial differentiation of contemporary demographic features in Baranya: 1 - area of stronger depopulation, 2 - area of socio-demographic depression, 3 - potential Baranya's developmental axis (a - population focus, $b$ - area of a greater gravitation (Osijek), $c$ - linking area of possible quicker revitalization)

Kakva su očekivana demografska kretanja, odnosno demografske perspektive Baranje? Za precizniji odgovor na ovo pitanje bila bi potrebna podrobnija analiza ne samo demografskih i geografskih, već i ekonomskih i drugih faktora koji određuju perspektivu i sudbinu ovog kraja. Kako takva analiza prerasta snage pojedinca i okvire ovoga rada, viđenje perspektive i daljnjeg razvoja demogeografskih procesa bazirano je na podacima demografske statistike, odnosno suvremenim dinamičkim i strukturnim obilježjima stanovništva Baranje.

Mogućnosti revitalizacije baranjskog prostora s postojećim ljudskim resursima su upitne, baš kao i gospodarska atraktivnost prostora, koja bi kao takva mogla pozitivno djelovati kroz ekonomsku imigraciju na usporavanje uočenih negativnih demografskih procesa i utjecati na demografski oporavak ovog kraja. Postojeći društveni i gospodarski resursi nisu u mogućnosti zaustaviti niti preokrenuti nepovoljne demografske, gospodarske i općedruštvene tokove. Dobna i obrazovna struktura ukazuju na činjenicu da je egzodus odnio prije svega mlađe i obrazovanije stanovništvo. Uz takvu starosnu strukturu stanovništva ne samo da nije moguće očekivati inventivnost i razvoj poduzetničkog duha, već se i postojeći resursi i kapaciteti slabo koriste. U mnogim je naseljima broj stanovnika toliko smanjen da je otežan i svaki pokušaj suvremene organizacije gospodarskih 
aktivnosti i društvenog života. Proklamirano društveno opredjeljenje s tržišnom ekonomijom kao temeljnim gospodarskim opredjeljenjem, ne ostavlja puno nade za pojedine dijelove, odnosno pojedina naselja Baranje. Svakoj odluci o ulaganjima potencijalnih investitora prethodi analiza svih čimbenika bitnih za realizaciju investicije i njenu ekonomsku opravdanost, pri čemu su bitni elementi i raspoloživost i kvalitativna obilježja ljudskih resursa prostora. U sadašnjim uvjetima postaje upitna opravdanost potencijalnih ulaganja, a to opet dovodi u pitanje izglede i mogućnosti obnove i revitalizacije ukupnog gospodarskog i društvenog života na ovom području.

U Nacionalnom programu demografskog razvitka, u kojem su navedene teorijske postavke hrvatske demografske i populacijske politike, Baranja je svrstana u ruralne prostore strateške važnosti, tj. prostore u kojima je nužno zaustaviti iseljavanje i usmjeravati doseljavanja. Jednako tako, Zakonom o područjima posebne državne skrbi ("Narodne novine", br. 88/02) ovaj je prostor, prema okolnostima nastalim na temelju stanja okupiranosti i posljedica agresije na Republiku Hrvatsku, u cijelosti svrstan u prvu kategoriju područja posebne državne skrbi, poradi otklanjanja posljedica rata, bržega povratka prognanika i poticanja demografskog i gospodarskog napretka. Ipak, unatoč tomu, bez osiguranja adekvatne financijske potpore proklamiranim mjerama populacijske politike, izostaje realizacija utvrđenih ciljeva, kako u Baranji tako i u drugim dijelovima Hrvatske sličnih demografskih obilježja. Tek osiguranje kvalitetnijih uvjeta života na tim prostorima, može rezultirati optimalnim brojem stanovnika i stabilnim dinamičkim i strukturnim demografskim značajkama. Za to je pak, nužno osigurati odgovarajuću materijalnu podlogu, jer će bez osiguranja potrebnih financijskih sredstava za provođenje smišljene poglavito gospodarske politike, izostati ekonomska revitalizacija, a upravo je ona temeljni preduvjet za zaustavljanje daljnjeg iseljavanja, povratak i naseljavanje, odnosno demografsku obnovu prostora. Bez osiguranja materijalnih pretpostavki za snažniji gospodarski razvoj, upitan je i povratak, a o naseljavanju mladih u Baranju, kao uostalom i u druga depopulacijska područja, nema govora. Zato se s puno sigurnosti može očekivati da će ovaj dio Hrvatske i u budućnosti gubiti stanovništvo i depopulirati. Dakako, proces depopulacije neće biti tako naglašen kao u posljednjem desetljeću (zbog rata), a izvjesno je i da će biti selektivniji kad je u pitanju prostorni obuhvat i broj naselja.

Uz nastavak procesa depopulacije za očekivati je da se i naslijeđena naseljska struktura u budućnosti neće moći održati. U budućem razdoblju realno je očekivati tek kod nekih naselja, poglavito uz glavnu baranjsku prometnicu koja povezuje Osijek s Belim Manastirom, zaustavljanje procesa depopulacije i saniranje demografskog gubitka iz zadnjeg međupopisnog razdoblja.

Proces koncentracije stanovništva u naselja središnjeg dijela Baranje (ne sva!) odvijat će se prije svega na račun daljnjeg demografskog slabljenja velikog broja malih naselja, poglavito u rubnim i prometno izoliranijim dijelovima. Kako je u razvoju prostora nužno voditi računa prije svega o kvaliteti ljudskog življenja, a što podrazumijeva osiguranje određenih blagodati urbanog života, odnosno urbane infrastrukture, "prorjeđivanje" mreže naselja javlja se kao neminovnost i neka naselja nije moguće "spasiti". Radi se o naseljima u kojima se nisu mogli stvoriti kvalitetni životni uvjeti primjereni suvremenom načinu života, ponekad i zbog prometne izoliranosti. "Takva sela ostala su po strani, izolirana, prepuštena sama sebi. Iseljavanje iz njih.....prirodan je proces koji u biti ima vremenski 
nedvojbenu društvenu opravdanost" (Nejašmić, I., 1991b: 242). Broj sitnih naselja (do 199 stanovnika) u Baranji je u zadnjem međupopisnom razdoblju povećan s jedanaest na petnaest. S obzirom na broj i dobni sastav stanovništva (izrazito duboka starost), neka će od tih naselja vrlo skoro ostati bez stanovnika i nestati kao antropogeografski pojam. Sasvim je izvjesno da sudbinu primjerice Sudaraža (,mrtvo naselje“), mogu očekivati i naselja: Zlatna Greda (12 stanovnika; $\left.x_{s}=500,0\right)$, Novo Nevesinje ( 73 stanovnika; $\left.x_{s}=155,6\right)$, Šrine (86 stanovnika; $\left.x_{s}=150,0\right)$, Podolje $\left(168\right.$ stanovnika; $\left.x_{s}=342,9\right)$ i dr. Pogreška učinjena Zakonom o obnovi ("Narodne novine", br. 24/96, 54/96, 87/96 i 57/00), kojim se ustraje na obnovi srušenih obiteljskih kuća na ranijoj lokaciji, u Baranji će biti barem djelomično ispravljena, budući se definitivno odustalo od obnove kuća u nekim naseljima-pustarama. Umjesto obnove na ranijim lokacijama u tim malim "besperspektivnim" naseljima, bit će, odnosno dijelom već i jesu, izgrađeni zamjenski stambeni objekti u susjednim većim naseljima; Grabovcu, Kneževim Vinogradima, Čemincu...

S obzirom na dominantna demogeografska obilježja i procese, kao i činjenicu da se danas ljudi kreću na puno širem prostoru negoli su to prije činili, da danas radijus lokalnog društva više nije 1-3 kilometra, već 10-30 kilometara (Puljiz, V., 1993), bitno je prepoznati potencijalne lokalne centre i poticati njihov razvoj kako bi se barem u njima zadržalo stanovništvo. Formiranje mreže naselja koja se relativno lako i brzo mogu transformirati u naselja s gradskim obilježjima i funkcijama, kojima mogu servisirati i okolna manja ruralna naselja, ublažilo bi i usporilo depopulaciju. "To bi bila sela koja se mogu razmjerno brzo razviti u naselja s gradskim obilježjima i tako zadovoljiti i neke elementarne potrebe okolnog seoskog stanovništva" (Nejašmić, I., 1991a: 14). Temeljnu ulogu u formiranju takve nove "naseljske armature" (Nejašmić, I., Toskić, A., 2000) imala bi općinska središta, naselja s oko 2000 stanovnika. U Baranji je prije Domovinskog rata, pored "velikih" naselja uz glavnu prometnicu, Belog Manastira, Darde i Bilja, mrežu lokalnih središta činilo još pet naselja izvan baranjskog prometno-gospodarskog koridora Osijek - Beli Manastir. To su bila naselja: Kneževi Vinogradi (2 127 stanovnika), Jagodnjak (1 951 stanovnik), Popovac (1 582 stanovnika), Branjin Vrh (1 578 stanovnika) i Batina (1 449 stanovnika). S obzirom na izuzetno veliko smanjenje broja stanovnika u tim naseljima u razdoblju 1991.-2001. (Kneževi Vinogradi za petinu, Branjin Vrh i Jagodnjak za četvrtinu, a Batina i Popovac skoro za trećinu), danas je, uvažavajući postojeće društveno-gospodarske uvjete, samo naselje Kneževi Vinogradi (1 715 stanovnika) zadržalo kakve-takve izglede za razvoj i preuzimanje uloge lokalnog središta. Ono je ujedno i jedino veće naselje koje je smješteno periferno u odnosu na glavnu prometnu i gospodarsku os Baranje.Nedostatak većeg naselja osobito je uočljiv u sjeveroistočnom dijelu, gdje najveća naselja, Popovac i Batina, jedva prelaze veličinu od tisuću stanovnika.

Vrlo je slična situacija i u zapadnom dijelu Baranje, gdje tek novi most i bolja prometna i gospodarska povezanost s valpovačko-belišćanskim prostorom, pruža mogućnost brže revitalizacije. 


\section{ZAKLJUČAK}

Suvremena demogeografska obilježja i procesi u Baranji zasigurno ne ulijevaju optimizam. Predočene značajke uočenih procesa, poglavito depopulacije, ukazuju da su ti procesi od posljedica prerasli u čimbenike društveno-gospodarskog razvitka. Pored dugogodišnjih niskih vrijednosti stopa nataliteta, emigracijom i negativnom selekcijom stanovništva, te ratom i progonstvom, pogoršana su strukturna obilježja stanovništva, poglavito biološka i obrazovna struktura.

Budući demografski razvoj Baranje ovisit će prije svega o gospodarskom razvitku, no malobrojno stanovništvo, uz nepovoljna dinamička i strukturna obilježja, postaje sve više ograničavajući čimbenik i gospodarskog oživljavanja ovog kraja.

S obzirom na nespornu funkcionalnu povezanost društveno-gospodarske nerazvijenosti i stupnja depopulacije s puno sigurnosti može se reći da je, uvažavajući sadašnju društveno-gospodarsku situaciju, rubni položaj i prometnu izoliranost pojedinih dijelova Baranje, iluzorno očekivati ekonomsku revitalizaciju ovog kraja bez sustavne, dosljednije i snažnije potpore države. Za rješavanje uočenih brojnih problema, poglavito glede demografske i gospodarske obnove, neophodna je državna pomoć, kako kroz konkretnu financijsku potporu donesenih mjera na razini države, tako i kroz aktiviranje znanstvenih i stručno-planskih institucija u cilju stvaranja uvjeta za oživljavanje društvenih i gospodarskih aktivnosti. Dakako, pri trom treba imati na umu da glavni cilj željenog demografskog oživljavanja nikako ne može biti obnova ukupnog broja stanovnika iz ranijih razdoblja najveće naseljenosti Baranje. S obzirom na društvene i gospodarske promjene koje su se tu dogodile zasigurno će se manji broj stanovnika pokazati optimalnim, te je potrebno usmjeriti nastojanja da se osiguranjem kvalitetnih uvjeta života osigura demografska stabilnost prostora. Pri tom treba imati na umu da je oživljavanje depopulacijskih naselja i prostora spor i dugotrajan proces koji se ne događa „preko noći“.

POZIVNE BILJEŠKE

1. Pri korištenju podataka iz publikacija navedenih kao izvor, prisutan je problem iskazivanja ukupnog stanovništva, budući se rezultati starijih popisa temelje na koncepciji "prisutnog stanovništva". S obzirom na temu, za rad su od presudnog značaja Popis 1991. i Popis 2001. Rezultati Popisa 1991., kao i svih drugih popisa provedenih u bivšoj državi, odnosili su se na tzv "stalno stanovništvo", tj. prema mjestu prebivališta svakog stanovnika bez obzira je li osoba u kritičnom trenutku popisa bila u mjestu popisa ili ne (de iure). U Popisu 2001. dolazi do primjene nove definicije ukupnog stanovništva. Ekonomska komisija za Europu i Eurostat koriste za ukupno stanovništvo naziv "uobičajeno stanovništvo", a kriterij je tzv. "uobičajeno mjesto stanovanja" uz vremensko ograničenje odsutnosti do dvanaest mjeseci. U Popisu 2001. djelomice je primijenjena preporuka za međunarodne migracije po kojoj je osoba preselila iz jedne u drugu zemlju kada protekne 12 mjeseci. Ipak je obuhvaćen i dio migranata koji su duže od 12 mjeseci u inozemstvu i koji češće kontaktiraju (dolaze) u domovinu. Ove razlike u načinu provedbe Popisa 2001. u odnosu na Popis 1991., treba imati u vidu kod usporedbe njihovih rezultata.

2. Naselje Podunavlje 2001. godine ima isti broj stanovnika kao i prije deset godina; 2 (dva) stanovnika. 
3. U metodološkom objašnjenju “Statistička izvješća" 1168/2000. se navodi: "Umjesto procjene broja stanovnika sredinom 2000. koristi se podatak o ukupnom broju stanovnika iz Prvih rezultata Popisa 2001., a umjesto procjene broja stanovnika sredinom 2001., koristi se podatak o ukupnom broju stanovnika iz konačnih rezultata Popisa 2001. Ocijenjeno je da je za izradu relativnih pokazatelja za niže teritorijalne jedinice Republike Hrvatske (županije) prihvatljiviji podatak o broju stanovnika iz Popisa 2001. (stanje 31. ožujka 2001.)" Shodno tomu, a imajući u vidu zbivanja na tom prostoru nakon 1991. pa do reintegracije, za izradu relativnih pokazatelja za baranjske jedinice lokalne samouprave, za godine 1998., 1999., 2000. i 2001., korišten je podatak o broju stanovnika iz Popisa 2001.

4. Podaci za razdoblje 1998.-2001. odnose se na kontingent "stanovništva u zemlji", tj. njegov broj i vitalne događaje (rođenja i smrti). Nije obuhvaćen kontingent "osoba na privremenom radu u inozemstvu i članova obitelji koji s njima borave", a niti vitalni događaji u inozemstvu, što je sukladno preporukama za definiranje ukupnog stanovništva (Statistička komisija UN-a i Eurostat) koje predlažu načelo "uobičajenog boravišta" (usual residence).

5. Naselja Podravlje i Tvrđavica, iako se nalaze na baranjskoj strani Drave, u administrativno teritorijalnom smislu nisu tretirana kao dio baranjskog prostora, odnosno dio bivše belomanastirske općine, već kao dio grada Osijeka.

6. Godine 1991., kao ni kasnije tijekom Domovinskog rata, Baranja nije bila u cijelosti okupirana. Tijekom rata bilo je pomicanja linije bojišnice, odnosno crte razdvajanja, no tzv. sjeverni mostobran grada Osijeka, osječka prigradska naselja Podravlje i Tvrđavicu i dio Kopačkog rita, oko 3 tisuće hektara površine, okupacijske snage nisu nikada uspjele osvojiti.

7. Indeks starosti $\left(\mathrm{x}_{\mathrm{S}}\right)$ prikazuje brojčani omjer stanovništva starijeg od 59 godina i mlađeg od 20 godina. Izračunava se po formuli: $\mathrm{x}_{\mathrm{S}}=(\mathrm{P}>59) /(\mathrm{P}<20) \times 100$.

8. Bez skupine "nepoznata dob".

9. Tip stanovništva po dobnom sastavu; kombinirana klasifikacija (prema: Nejašmić, I., 1991: 175): a) mladost $\left(\mathrm{x}_{\mathrm{s}}=\right.$ do $\left.\left.22,9 \%\right), \mathrm{b}\right)$ na pragu starenja $\left.\left(\mathrm{x}_{\mathrm{s}}=23,0-34,9 \%\right), \mathrm{c}\right)$ starenje $\left.\left(\mathrm{x}_{\mathrm{s}}=35,0-44,9 \%\right), \mathrm{d}\right)$ starost $\left(\mathrm{x}_{\mathrm{s}}=45,0\right.$ - 54,9\%), e) duboka starost $\left(\mathrm{x}_{\mathrm{s}}=55,0-99,9 \%\right)$, f) izrazito duboka starost $\left(\mathrm{x}_{\mathrm{s}}=100,0\right.$ i više \%).

10. Aktivno stanovništvo u zemlji. Nisu uključeni naši građani na radu u inozemstvu kod stranog poslodavca, budući Popis ne daje podatke o aktivnosti, odnosno području djelatnosti "stanovništva u inozemstvu" ("na radu").

\section{LITERATURA}

Ćurčić S., Kicošev S., 1993: Razvoj populacije Baranje, Biblioteka „Baranja“. Beli Manastir - Novi sad.

Friganović M., 1984: Egzodusna područja, (ne)razvijenost i populacijska politika u SR Hrvatskoj, Radovi, Zagreb, 19, 29-37.

Mendras H., 1986: Seljačka društva: elementi za jednu teoriju seljaštva, Globus, Zagreb.

Nejašmić I., 1991a: Moguća revitalizacija sociodemografskih depresivnih (seoskih) područja Hrvatske, Sociologija sela, Zagreb, br.111-114,11-24.

Nejašmić I., 1991b: Depopulacija u Hrvatskoj, Korijeni, stanje, izgledi, Globus, Zagreb.

Nejašmić I., Toskić A., 2000: Raznještaj stanovništva u Republici Hrvatskoj, Geoadria. Zadar, 5, 93-104.

Puljiz V., 1993: Ljudski faktor i ruralni razvitak Hrvatske, Sociologija sela, Zagreb, 31, 11-12.

Šterc S., 1983: Prirodno kretanje stanovništva prigraničja SR Hrvatske prema Mađarskoj, Geografski glasnik, Zagreb, 45, 119-139.

Wertheimer-Baletić A., 1978: Ekonomska aktivnost stanovništva, Demografski aspekti, Školska knjiga, Zagreb. Wertheimer-Baletić A., 1988: Razvoj stanovništva na području ZO Bjelovar, Knjiga 439, JAZU, Zagreb, 99-135.

Wertheimer-Baletić A., 1999: Stanovništvo i razvoj, Mate d. o. o., Zagreb. 


\title{
SUMMARY
}

\section{Population Development of Baranya (Croatia) 1991-2001}

\author{
Pavo Šašlin
}

This paper analyzes population features and processes in Baranya, the north-eastmost part of the Republic of Croatia. The emphasis is on the last inter-census period, when, under the impact of social factors, especially the political ones, great demographic changes took place.

Frequent oscillations of the total population number that have marked the historical development of Baranya, characterize the 20th century last decade as well. The socio-historical happenings from the end of the last century had an essential impact on the greatest inter-census population number decrease in this area. Because of the exile after the occupation, war losses, further worsening of the natural change, no return and out-migration after reintegration, the total population number declined for more than a fifth in relation to 1991. Although the tendencies of demographic regression in this part of Croatia had not been clearly visible before, the occupation, war and accompanying social phenomena and processes fastened and intensified it even more. These days, depopulation process is a dominant characteristic of Baranya, all its administrative-territorial units and, practically, all settlements. General population density of this region is more than a half smaller in comparison to that of the County of Osijek-Baranya, of which Baranya makes an integral part.

Natural decrease, which had appeared in this part of Croatia even before 1991, is an essential population factor. In the last decade, the natural, reproductional depopulation in Baranya visibly advanced, so today, it is significantly more emphasized than in the remaining part of the country. Besides very low values of the reproduction rates, an important determinant of natural decrease is more and more a high value of the annual death rates, which is the consequence of an unfavourable age structure.

The consequence of the occupation and war were forced migrations of great proportions, which, among other things, essentially changed the population ethnic structure. Migrations continued during and after the peaceful reintegration process of this area into the constitutional and legal system of the Republic of Croatia. In the end, they resulted in the total population number decrease, but also in worsening of the Baranya population dynamic and structural features.

Higher feminity index, i. e. a greater share of women in the total population of Baranya with regard to the country, does not point to a greater economic development of that part of Croatia, but it is the consequence of the male population greater suffering during the occupation and war, as well as of the total population old age.

The age structure is characterized by a high degree of population old age. Traditionally low natality, with rural exodus and negative demographic change connected with the Croatian War of Independence, resulted in a very pronounced ageing process. In 2001, the old-age index shows that the population of Baranya had moved very close to the age structure type: a markedly deep old age.

Aggravation of the educational structure is also noticeable, especially with the high-educated share in the total population, so the lagging behind the population education structure on the country level is more and more pronounced. The present educational structure, with the active population number decrease and existing features of the population biological structure, represents a bad starting basis for a necessary revival of this part of the Croatian Danube basin.

In the course of the last decade, there was a spatial redistribution of population with the total population number and density declines. Further concentration of population in the central, econo- 
mically more active part of Baranya is visible along the principal road and railway traffic direction, while the peripheral parts, economically more inferior rural areas, lose population. This especially relates to the north-eastern part. By its demographic and economic characteristics it represents an especially depressive area.

First of all, the active population at reproductional age took part in the population removal from the Baranya villages into urban and urbanized settlements, which contributed to positive demographic changes in those settlements, while negative polarization effects in other settlements resulted in their depopulation, sometimes even in dying away. Today, negative population and social processes dominate in rural settlements. Socio-demographic consequences of a decades-long deagrarization and deruralization are visible in the total population number decline, as well as in significant disorders concerning natural dynamics, age-sex and economic structures of those settlements' population.

The population concentration process towards the larger settlements of the central part will continue at the expense of further weakening of small settlements, especially because of the population number decrease in the border, isolated ones. Therefore, it is realistic to expect further "thinning out" of the existing settlement net, i. e. the settlement number decline.

Depopulation, markedly unfavourable biological and structural features of population, weakening and collapse of economy are indisputably fundamental contemporary features of Baranya. Characteristics of the recognized processes, especially of depopulation, show that those processes have developed from the consequences into the factors of socio-economic development. A small number and unfavourable structural features of the population represent a confining factor of the area's social and economic revival. At the same time, as demographic development depends primarily on economic development, a bad economic situation and total social atmosphere in Baranya make the demographic revival a very questionable one.

Strengthening of economic activities is certainly the basic prerequisite of the wanted demographic recovery. Therefore, a stronger state support of economic activities would be necessary for the revitalization of this part of Croatia, or, at least, for slowing down or stopping the visible markedly negative tendencies. Of course, in this matter, it is necessary to avoid dependence upon the programmes and policies, which are trying to eliminate symptoms, not causes of the present situation. It is necessary to assure a developmental approach, the approach based on the existing resource evaluation, in which process the analysis of the young population position requires a special attention, especially its possibilities and capabilities for assuming the role of this region's complete revitalization bearer. Accordingly, the application of the stimulative measures and supports regulated by the Special Development Area Act, must be real and consistent.

Primljeno (Received): 1 - 2 - 2005

Prihvaćeno (Accepted): $11-5-2005$

Pavo Šašlin mr. sc., viši stručni savjetnik, Ministarstvo mora, turizma, prometa i razvitka, Uprava za regionalni razvoj, Nazorova 61, 10000 Zagreb, Hrvatska/Croatia

E-mail: pavo.saslin@ws.mmtpr.hr 